\title{
Salt Disposition Alterrnatives Filtration at SRTC
}

by

B. W. Walker

Westinghouse Savannah River Company

Savannah River Site

Aiken, South Carolina 29808

B. W. Walker

D. Hobbs

This paper was prepared in connection with work done under the above contract number with the U. S. Department of Energy. By acceptance of this paper, the publisher and/or recipient acknowledges the U.S. Government's right to retain a nonexclusive, royalty-free license in and to any copyright covering this paper, along with the right to reproduce and to authorize others to reproduce all or part of the copyrighted paper. 


\section{DISCLAIMER}

This report was prepared as an account of work sponsored by an agency of the United States Government. Neither the United States Government nor any agency thereof, nor any of their employees, makes any warranty, express or implied, or assumes any legal liability or responsibility for the accuracy, completeness, or usefulness of any information, apparatus, product or process disclosed, or represents that its use would not infringe privately owned rights. Reference herein to any specific commercial product, process or service by trade name, trademark, manufacturer, or otherwise does not necessarily constitute or imply its endorsement, recommendation, or favoring by the United States Government or any agency thereof. The views and opinions of authors expressed herein do not necessarily state or reflect those of the United States Government or any agency thereof.

This report has been reproduced directly from the best available copy.

Available for sale to the public, in paper, from: U.S. Department of Commerce, National Technical Information Service, 5285 Port Royal Road, Springfield, VA 22161, phone: (800) 553-6847, fax: (703) 605-6900

email: orders@ntis.fedworld.gov

online ordering: http://www.ntis.gov/ordering.htm

Available electronically at http://www.doe.gov/bridge

Available for a processing fee to U.S. Department of Energy and its contractors, in paper, from:

U.S. Department of Energy, Office of Scientific and Technical Information, P.O. Box 62,

Oak Ridge, TN 37831-0062,

phone: (865)576-8401,

fax: (865) 576-5728

email: reports@adonis.osti.gov 


\section{DISCLAIMER}

Portions of this document may be illegible in electronic image products. Images are produced from the best available original document. 
Westinghouse Savannah River Company Savannah River Technology Center

Keywords: Filtration, In-Tank Precipitation Alternatives

Retention: Permanent

Salt Disposition Alternatives Filtration at SRTC

September 30, 1998

B. W. Walker, 773-42A

J. L. Siler, 773-43A

Savannah River Technology Center

Westinghouse Savannah River Company

Aiken, SC 29808 


\section{Summary}

Several of the prospective salt disposition alternative technologies require a monosodium titanate (MST) contact to remove strontium and actinides from inorganic salt solution feedstock. This feedstock also contains sludge solids from waste removal operations and may contain defoamers added in the evaporator systems. Filtration is required to remove the sludge and MST solids before sending the salt solution for further processing.

This report describes testing performed using the Parallel Rheological Experimental Filter (PREF). The PREF contains two single tube Mott sintered metal crossflow filters. For this test one filter was isolated so that the maximum velocities could be achieved. Previous studies showed slurries of MST and sludge in the presence of sodium tetraphenylborate (NaTPB) were filterable since the NaTPB slurry formed a filter cake which aided in removing the smaller MST and sludge particles.

Some of the salt disposition alternative technologies do not use NaTPB raising the question of how effective crossflow filtration is with a feed stream containing only sludge and MST. Variables investigated included axial velocity, transmembrane pressure, defoamer effects, and solids concentration (MST and sludge). Details of the tests are outlined in the technical report WSRC-RP-98-00691. ${ }^{1}$

Key conclusions from this study are:

- Severe fouling of the Mott sintered metal filter did not occur with any of the solutions filtered.

- The highest fluxes, in the range of .46 to $1.02 \mathrm{gpm} / \mathrm{f}^{2}$, were obtained when salt solution decanted from settled solids was fed to the filter. These fluxes would achieve 92 to $204 \mathrm{gpm}$ filtrate production for the current ITP filters. The filtrate fluxes were close to the flux of $0.42 \mathrm{gpm} / \mathrm{f}^{2}$ reported for In Tank Precipitation Salt Solution by Morrisey. ${ }^{2}$

- For the range of solids loading studied, the filter flux ranged from .04 to $.17 \mathrm{gpm} / \mathrm{f}^{2}$ which would result in a filtrate production rate of 9 to $31 \mathrm{gpm}$ for the current ITP filter.

- Filtrate flux for slurries containing solids and defoamers was between the range of .04 to $.13 \mathrm{gpm} / \mathrm{f}^{2}$ which is better than the average flux of $0.024 \mathrm{gpm} / \mathrm{f}^{2}$ reported for Late Wash. $^{3}$ 
- Filtrate flux is weakly dependent on the variables of insoluble solids concentration, defoamer concentration, transmembrane pressure, axial velocity, and filtration time.

The following are typical responses that were recorded:

$\underline{\text { Variable }}$

Insoluble Solids

Defoamers

Transmembrane

Pressure

Axial Velocity

Filtration Time
Variable range

Suspended Fines

$620 \mathrm{ppm}$, no defoamers

9300 ppm, no defoamers

$0 \mathrm{ppm}$ defoamers

400 ppm defoamers

Suspended Fines

(15 - 45 psid)

Other filter solutions

(15-45 psid)

Suspended Fines

$(4-14 \mathrm{f} / \mathrm{s})$

Other filter solutions

$(4-14 \mathrm{f} / \mathrm{s})$

Suspended Fines

(Filtration start - stop)

Filter solutions, no defoamers

(Filtration start - stop)

Filter solutions, with defoamers (Filtration start - stop)
Filtrate Flux

Response $\mathrm{gpm} / \mathrm{f}^{2}$

$.2-1.0$

$.08-.17$

$.05-.14$

$.05-.17$

$.04-.13$

$.2-1.0$

$.04-.17$

$.46-.84$

$.08-.1$

$.65-.9$

$.13-.09$

(avg)

$.11-.09$

(avg) 


\section{Experimental}

The Parallel Rheological Experimental Filter (PREF) was employed to conduct the filtration studies. Variables investigated included axial velocity, defoamer effects, time, transmembrane pressure drop across the filter, and the presence of sludge and MST. Transmembrane pressure drop is equal to (filter inlet pressure + filter outlet pressure)/2 filtrate pressure.

A sketch of the PREF appears in Figure 1 and an actual picture of the apparatus in Figure 2. For this study with the PREF only filter \#1 was used with the second filter being isolated so that the maximum velocity necessary for the tests could be achieved. The filter measures 4 feet in length having an internal diameter of 0.5 inches with .5 micron pore size and an active filter area of $0.52 \mathrm{f}^{2}$. A progressive cavity positive displacement pump manufactured by Moyno Industries provided slurry flow.

Figure 1.

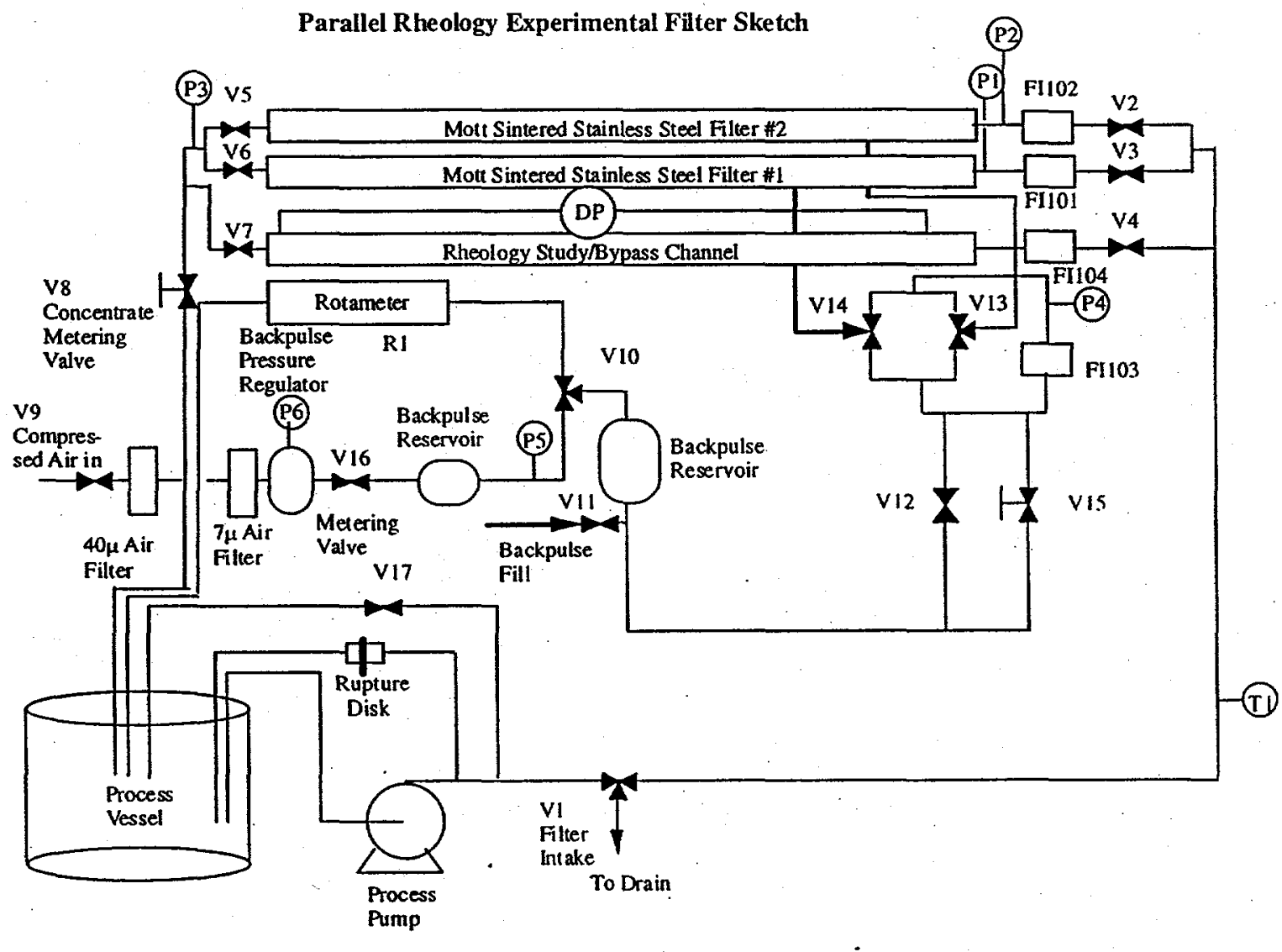




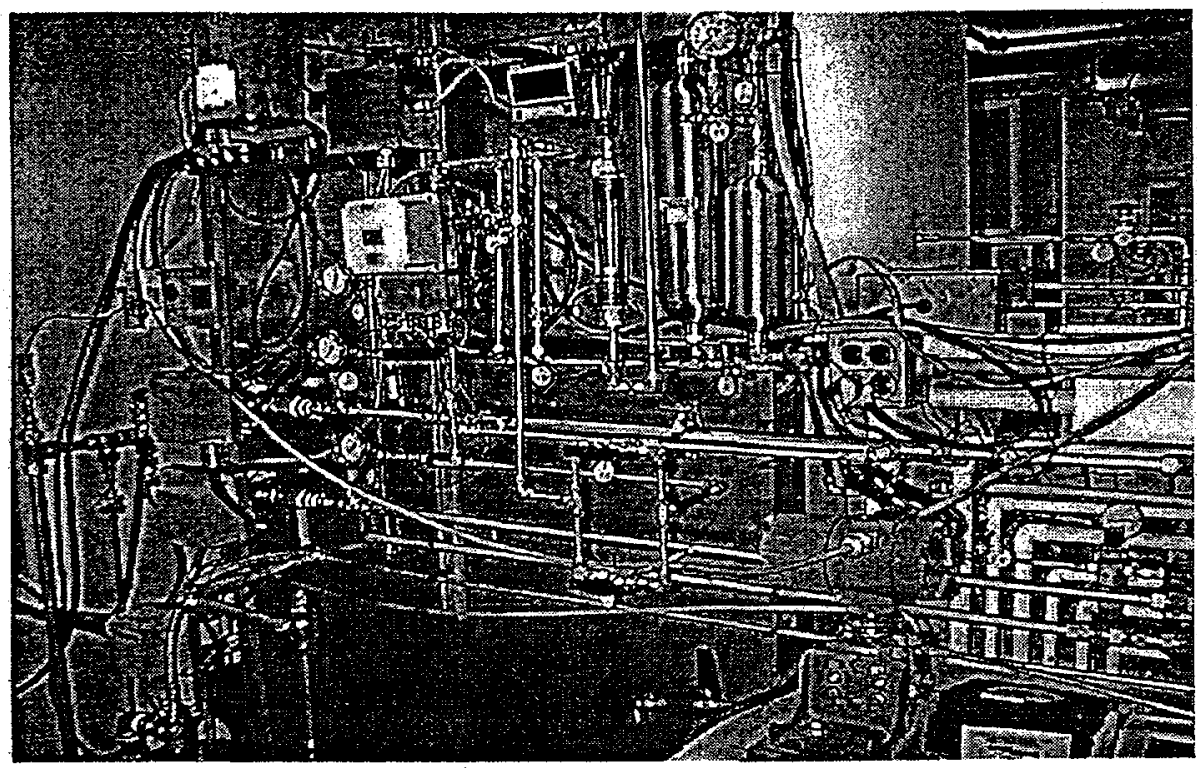

The Axial Velocity and Transmembrane Pressure were varied as shown in Table 1. The system temperature was controlled at $35+/-2$ degrees $C$ using a heater cooler unit which circulated heated or cooled water through a coil in the slurry feed tank.

Table 1. Operational parameter matrix

\begin{tabular}{lll}
$\begin{array}{l}\text { Test } \\
\text { Number }\end{array}$ & $\begin{array}{l}\text { Axial } \\
\text { Velocity (f/s) }\end{array}$ & $\begin{array}{l}\text { Transmembrane } \\
\text { Pressure (psid) }\end{array}$ \\
\cline { 2 - 3 } 2 & 9 & 30 \\
3 & 12 & 40 \\
4 & 4 & 30 \\
5 & 9 & 15 \\
6 & 12 & 20 \\
7 & 9 & 30 \\
8 & 6 & 40 \\
9 & 9 & 45 \\
10 & 14 & 30 \\
11 & 6 & 20 \\
& 9 & 30
\end{tabular}

Process variables measured included inlet, discharge, and filtrate pressure, discharge flow rate, filtrate flow rate, and temperature. A backpulse of the filter was performed every 45 minutes at the beginning of each test point during matrix testing. 
The salt solution chemical component quantities for the amount of slurry we needed were determined using Table 2 which lists the salt solution components for 1 kilogram of this slurry. Solution 1 and 2 were prepared separately, then Solution 2 was added to Solution 1 over a period of 15 minutes while agitating. The combined solution was stirred an additional hour. Sludge solution was added to bring its concentration to $6000 \mathrm{ppm}$ and MST solution was added to bring its concentration to $3300 \mathrm{ppm}$. The slurry was allowed to remain at rest for 3 days to settle sludge and MST solids.

\section{Table 2. Chemicals needed for 1 kilogram of Salt Solution}

\begin{tabular}{|c|c|c|c|}
\hline Solution \#1 & & Solution \#2 & \\
\hline Component & Amount (grams) & Component & Amount (grams) \\
\hline Water & 400 & Water & $\begin{array}{l}225.5 \text { minus } \\
\text { MST/Sludge amount }\end{array}$ \\
\hline KNO3 & 1.09 & & \\
\hline $\mathrm{Na} 2 \mathrm{CO} 3$ & 14.2 & $\mathrm{NaOH}$ & 118.6 \\
\hline $\mathrm{Na} 2 \mathrm{SO} 4$ & 17.723 & $\mathrm{Al}(\mathrm{NO} 3) 3 * 9 \mathrm{H} 2 \mathrm{O}$ & 98.73 \\
\hline $\mathrm{NaCl}$ & 1.315 & & \\
\hline $\mathrm{NaF}$ & 1.148 & & \\
\hline $\mathrm{Na} 2 \mathrm{C} 2 \mathrm{O} 4$ & 0.546 & & \\
\hline $\mathrm{NaNO} 3$ & 90.065 & & \\
\hline $\mathrm{NaNO} 2$ & 31.06 & & \\
\hline
\end{tabular}

The supernate (Suspended Fines) from the salt solution with sludge and MST was separated from the fraction containing the insoluble solids. The decanted salt solution was filtered using the statistically designed 11 point test matrix in Table 1 . Next, a portion of the settled insoluble solids was added to provide $400 \mathrm{ppm}$ sludge and $220 \mathrm{ppm}$ MST (620 ppm total solids) and the 11 point test matrix was repeated. Solids from the settled solids soluton were then added to achieve $6000 \mathrm{ppm}$ sludge and $3300 \mathrm{ppm}$ MST $(9300 \mathrm{ppm}$ total solids) then the test matrix was performed.

The salt solution slurry was then allowed to settle three days to once again allow separation of the supernate and solids. The supernate was pumped at a low rate to the PREF feed tank so that settled solids would not be transferred. The concentration of the solids in the settled solids solution after the supernate separation was determined.

Settled solids were then added to the slurry in the feed tank to provide $400 \mathrm{ppm}$. sludge and $220 \mathrm{ppm}$ MST ( $620 \mathrm{ppm}$ total solids) and the test matrix was repeated. The $400 \mathrm{ppm}$ concentration was repeated to verify results obtained during the filtration study conducted at this concentration could be restablished after filtration of the high solids concentration of $9300 \mathrm{ppm}$. Settled solids solution was again added to the feed tank to provide 800 ppm sludge and $440 \mathrm{ppm}$ MST (1240 ppm total solids). 
At this point, Dow Antifoam B and Dow $\mathrm{H}-10$ were also added to give $200 \mathrm{ppm}$ of each surfactant. The fifth filter study was conducted on this slurry containing solids and the two surfactants using the test matrix. The sixth and seventh filtration tests were performed using the standard test matrix after the total insoluble solids concentration of the filtration slurry with the two surfactants was increased to $1600 \mathrm{ppm}$ sludge and 880 ppm MST (2480 ppm total solids) and 3200 ppm sludge and 1760 ppm MST (4960 ppm total solids) respectively.

The total solids levels referred to in this filtration study are the target levels for total insoluble solids that were specified in the workscope. The actual solids loadings levels were within tolerance levels (target $+/-20 \%$ ) defined in the workscope and were determined by washing a known amount of slurry with deionized water until all adhering soluble solids were removed. The remaining solids were dried and the total insoluble solids in the sample calculated. Table 3 gives a summary of the actual total insoluble solids loadings of various slurries. Only four concentrations of total insoluble solids were determined as spot checks to verify good solids level control.

Table 3

$\begin{array}{llll}\begin{array}{l}\text { Total Suspended } \\ \text { Solids Target }\end{array} & \begin{array}{l}\text { Defoamers } \\ \text { (yes/no) }\end{array} & \begin{array}{l}\text { Test Matrix } \\ \text { Position }\end{array} & \begin{array}{l}\text { Total Suspended } \\ \text { Solids Actual }\end{array} \\ 620 \mathrm{ppm} & \text { no } & \text { filtration end } & 810 \mathrm{ppm} \\ 1240 \mathrm{ppm} & \text { yes } & \text { filtration beginning } & 1225 \mathrm{ppm} \\ 1240 \mathrm{ppm} & \text { yes } & \text { filtration midpoint } & 1200 \mathrm{ppm} \\ 1240 \mathrm{ppm} & \text { yes } & \text { filtration end } & 1300 \mathrm{ppm} \\ 2480 \mathrm{ppm} & \text { yes } & \text { filtration beginning } & 2525 \mathrm{ppm} \\ 2480 \mathrm{ppm} & \text { yes } & \text { filtration midpoint } & 2220 \mathrm{ppm} \\ 2480 \mathrm{ppm} & \text { yes } & \text { filtration end } & 2115 \mathrm{ppm} \\ 4960 \mathrm{ppm} & \text { yes } & \text { filtration beginning } & 4055 \mathrm{ppm} \\ 4960 \mathrm{ppm} & \text { yes } & \text { filtration midpoint } & 4315 \mathrm{ppm} \\ 4960 \mathrm{ppm} & \text { yes } & \text { filtration end } & 5095 \mathrm{ppm}\end{array}$

\section{Results from Settled Salt Solution Supernate (Suspended Fines) Filtration}

A model was developed using a linear regression routine in Excel software to predict the filtrate flow behavior of the supernate of salt solution with sludge and MST after it had been settled for three days. (This solution is thought to contain suspended fines particles.) The result of this effort is an equation to describe the filtrate flux $\left(\mathrm{Q}, \mathrm{gpm} / \mathrm{f}^{2}\right)$ as a function of a number of parameters:

$\mathrm{Q}=0.618-.016 \mathrm{P}+.043 \mathrm{~V} \quad$ (Equation 1$)$

Where $\mathrm{P}$ is the transmembrane pressure drop across the filter in psi and $\mathrm{V}$ is the axial velocity of the slurry through the filter in $\mathrm{ft} / \mathrm{s}$. These results indicate that pressure drop 
and axial velocity are not statistically significant variables with respect to filtrate flux for this data set.

Inspection of Figure 3 of Supernate from Settled Salt Solution (Suspended Fines) filtrate flux vs axial velocity show that flux increases slightly until reaching a maximum around $9 \mathrm{f} / \mathrm{s}$ then slightly decreases. Since the analysis of the results indicates the filtrate flux does not increase significantly with axial velocity, formation of a filter cake on the filter surface should not be occurring to a large extent. The amount of solids in the slurry may not be great enough to cause a significant filter cake to form.

\section{Figure 3. Filtrate Flux vs Axial Velocity for Suspended Fines}

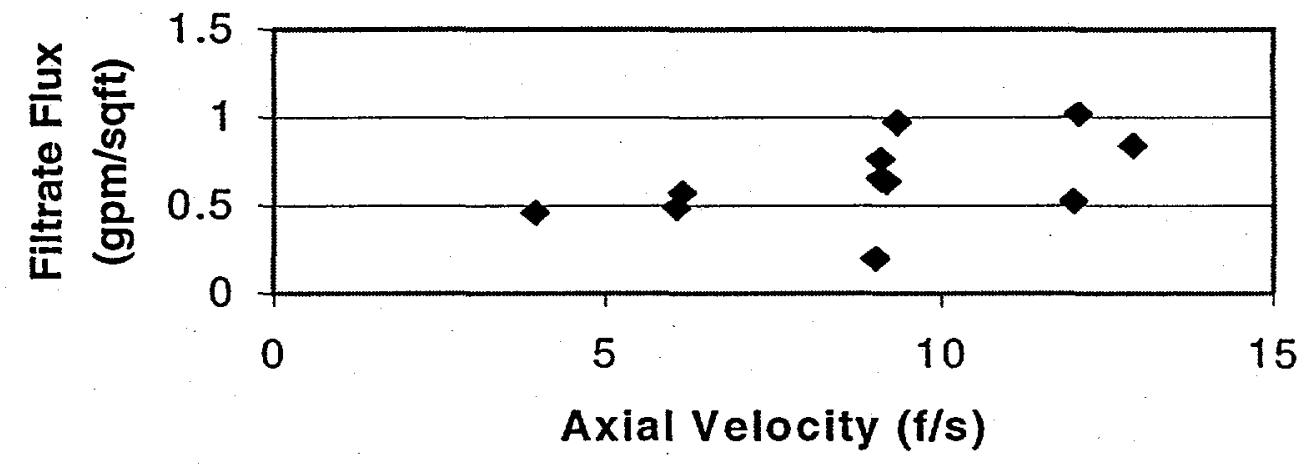

Figure 4 contains a plot of filtrate flux vs transmembrane pressure drop. Since the statistical analysis of the results indicates the filtrate flux does not increase significantly with transmembrane pressure drop, development of cake in the pores of the filter is probably not occurring. Once again, a cause of this behavior could be the relatively low concentrations of solids in the slurry.

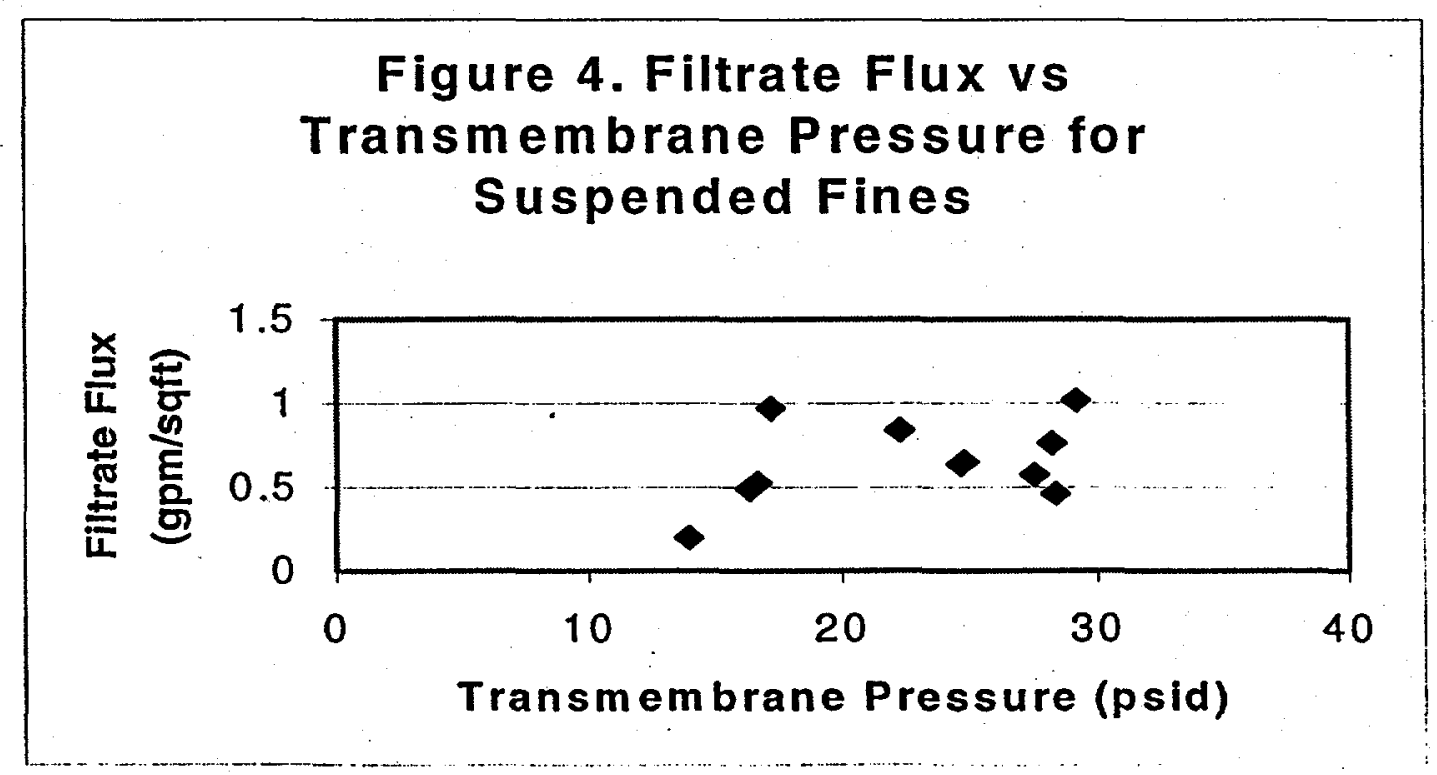


Turbidity results for the suspended fines solution are shown in Table 4. Supernate filtrate Net Transfer Units (NTUs) were only slightly less than that of the feed solution to the filter indicating almost no solids had been transferred from the settled salt solution with sludge and MST.

Table 4.

$\underline{\text { Description }}$

Nephelometric Turbidity

Net Transfer Units (NTUs)

Supernate Slurry, Time $=45$ minutes $\quad 6.84$

Supernate Filtrate, Time $=46$ minutes $\quad 6.08$

Supernate Filtrate, Time $=47$ minutes $\quad 5.58$

Supernate Filtrate, Time $=49$ minutes $\quad 5.21$

\section{Results from Different Concentrations of Total Solids and Defoamers}

Filtrate fluxes were obtained under a wide variety of conditions for solutions containing different concentrations of total solids and defoamers. From these experiments, a model was developed using Excel linear regression to predict the filtrate flow. It was found that the Suspended Fines flux data could not be included in the model because the high range of flux in respect to other filter solutions biased the effects of other variables. The result of this effort is an equation to describe the filtrate flux $\left(\mathrm{Q}, \mathrm{gpm} / \mathrm{f}^{2}\right)$ as a function of a number of parameters:

$Q=0.035-4.13 e-5 D+0.00212 P-5.08 \mathrm{e}-6 \mathrm{~S}+0.00326 \mathrm{~V}-2.17 \mathrm{e}-6 \mathrm{~T}$

(Equation 2)

$D$ is the concentration of defoamer in ppm

$P$ is the transmembrane pressure drop across the filter in psi

$\mathrm{S}$ is the concentration of solids in ppm

$\mathrm{V}$ is the axial velocity of the slurry through the filter in $\mathrm{ft} / \mathrm{s}$

$\mathrm{T}$ is the filtration time in minutes

Analysis indicates that defoamer concentration, total solids concentration, transmembrane pressure drop and axial velocity are statistically significant variables with respect to filtrate flux (95\% probability). Statistical significance means that there is a defininte response of filtrate flux when theșe variables are changed but this response is not large in magnitude and reveals only a weak dependence.

The fact that the filtrate flux is significant with velocity indicates a filter cake is being generated. The filtrate flux being statistically significant with respect to transmiembrane pressure drop indicates that particles are being caught in the pores of the filter and affecting the filtrate flux. The defoamer and solids concentration cause a decrease in filtrate flux according to this model. 
Individual models were also developed by linear regression for each type of filtration solution that was used to provide additional insight to differences in behavior for transmembrane pressure, axial velocity, and filtration time.

\begin{tabular}{|c|c|c|c|}
\hline PPM solids & Defoamer & Eq\# & Equation \\
\hline 620 & no & 3 & $\mathrm{Q}=0.0809+0.0028 \mathrm{P}+0.00257 \mathrm{~V}-8.7 \mathrm{e}-5 \mathrm{~T}$ \\
\hline 9300 & no & 4 & $\mathrm{Q}=0.1349+0.0011 \mathrm{P}+0.00543 \mathrm{~V}-.00011 \mathrm{~T}$ \\
\hline 620 & no & 5 & $\mathrm{Q}=0.053+0.00297 \mathrm{P}+0.0029 \mathrm{~V}-2.34 \mathrm{e}-5 \mathrm{~T}$ \\
\hline 1240 & yes & 6 & $\mathrm{Q}=0.0577+0.0022 \mathrm{P}+0.0036 \mathrm{~V}-2.63 \mathrm{e}-5 \mathrm{~T}$ \\
\hline 2480 & yes & 7 & $\mathrm{Q}=0.0703+0.0019 \mathrm{P}+0.00206 \mathrm{~V}-2.1 \mathrm{e}-5 \mathrm{~T}$ \\
\hline 4960 & yes & 8 & $\mathrm{Q}=0.155+0.0016 \mathrm{P}+0.00342 \mathrm{~V}-4.72 \mathrm{e}-5 \mathrm{~T}$ \\
\hline
\end{tabular}

Regression analysis results revealed that transmembrane pressure and axial velocity were statistically significant for equations $3,4,5,6,7,8$ but filtration time was significant only for equations $3,4,5$. Velocity being significant means the mechanism of filter cake forming on the filter surface is affecting filtrate flux appreciably for all cases. Transmembrane pressure being significant indicates filter cake forming in the filter pores is affecting filtrate flux for all cases. Filtration time being significant for equations $3,4,5$ and not for $6,7,8$ indicates filtrate flux is decreasing with time greater for solutions without defoamers than with those solutions with defoamers.

Turbidity results for the 620 and $9300 \mathrm{ppm}$ slurries and filtrates without defoamers are shown in Table 5. The fact that $620 \mathrm{ppm}$ Total Solids slurry NTU readings were consistently close to 100 NTUs and the filtrate readings were close to 5 indicates that solids are not being passed through the filter. Also NTUs do not seem to increase during backpulsing. This suggests this action does not cause increased transfer of solids through the filter.

\section{Table 5.}

\section{Description}

$620 \mathrm{ppm}$ Total Solids, no defoamer

Slurry, Time $=540$ minutes

Filtrate, Time $=542$ minutes

Filtrate, Time $=543$ minutes

Filtrate, Time $=545$ minutes

Slurry, Time $=765$ minutes

Filtrate, Time $=766$ minutes

Filtrate, Time $=767$ minutes

Filtrate, Time $=769$ minutes

Slurry, Time $=950$ minutes

Filtrate, Time $=952$ minutes

Filtrate, Time $=953$ minutes

Filtrate, Time $=955$ minutes
Nephelometric Turbidity

Net Transfer Units (NTUs)

96.04

4.43

4.55

5.62

114.02

3.92

5.15

4.78

108.6

5.3

4.95

3.74 
Table 5. Continued

Description

$9300 \mathrm{ppm}$ Total Solids, no defoamer

Slurry, Time $=990$ minutes

Filtrate, Time $=992$ minutes

Filtrate, Time $=993$ minutes

Filtrate, Time $=995$ minutes

Slurry, Time $=1260$ minutes

Filtrate, Time $=1262$ minutes

Filtrate, Time $=1263$ minutes

Filtrate, Time $=1265$ minutes

Slurry, Time $=1485$ minutes

Filtrate, Time $=1487$ minutes

Filtrate, Time $=1488$ minutes

Filtrate, Time $=1490$ minutes
Nephelometric Turbidity

Net Transfer Units (NTUs)

$>180$

4.51

3.74

4.18

$>180$

4.1

3.94

3.64

$>180$

5.37

3.3

2.99

Inductively coupled plasma- emission spectroscopy (ICP-ES) analyses for calcium, iron, manganese, and titanium were performed on slurry and filtrate samples to track insoluble solids levels and are given in Table 6. The low levels of $\mathrm{Fe}$ in the Suspended fines data tells us that there are low levels of solids in this solution. The ratios of $\mathrm{Fe}$ in other concentrations confirm that appropriate proportions of solids were present during the filtration and that solids were not being lost to a great extent due to the filtration process. The large difference between filtrate and slurry concentrations of insoluble solids indicates that we are not carrying solids over or through the filter even with different solids loadings.

\section{Table 6.}

\section{Description}

Supernate (Suspended Fines)

Slurry, Time $=45$ minutes

Filtrate, $\mathrm{T}=45$ minutes

Slurry, $\mathrm{T}=270$ minutes

Filtrate, $T=270$ minutes

Slurry, $T=495$ minutes

Filtrate, $\mathrm{T}=495$ minutes

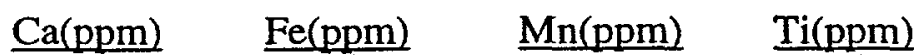

21.49

22.82

27.48

23.23

23.69

25.75
9.167

13.298

4.45

10.55

6.97

10.04
$<.7$

$<.7$

$<7$

$<.7$

$<.7$

$<.7$
$<.71$

$<.71$

$<71$

$<.71$

$<.71$

$<.71$ 
Table 6. (Continued)

\section{Description}

$620 \mathrm{ppm}$, no defoamer

Slurry, Time $=540$ minutes 38.99

Filtrate, $\mathrm{T}=540$ minutes

Slurry, $\mathrm{T}=270$ minutes

Filtrate, $\mathrm{T}=270$ minutes

Slurry, $T=950$ minutes

Filtrate, $\mathrm{T}=950$ minutes

$9300 \mathrm{ppm}$, no defoamer

Slurry, Time $=990$ minutes

Filtrate, $T=990$ minutes

Slurry, $T=1260$ minutes

Filtrate, $T=1260$ minutes

Slurry, $T=1485$ minutes

Filtrate, $\mathrm{T}=1485$ minutes

193.61

21.639

111.174

22.99

202.92

23.52

$620 \mathrm{ppm}$, no defoamer

Slurry, Time $=1530$ minutes 32.42

Filtrate, $T=1530$ minutes

26.86

Slurry, $T=1755$ minutes

Filtrate, $\mathrm{T}=1755$ minutes

Slurry, $T=1935$ minutes

32.99

21.77

Filtrate, $\mathrm{T}=1935$ minutes

28.0

29.0

$1240 \mathrm{ppm}$, with defoamer

Slurry, $T=1980$ minutes

Filtrate, $\mathrm{T}=1980$ minutes

Slurry, $\mathrm{T}=2250$ minutes

Filtrate, $\mathrm{T}=2250$ minutes

Slurry, $T=2430$ minutes

Filtrate, $\mathrm{T}=2430$ minutes
39.0

18.0

38.0

17.0

38.0

20.0
32.52

4.43

158.28

6.9

155.55

6.50

1926.2

4.942

1186.84

3.99

1929.42

7.75

127.55

3.88

116.8

3.12

120.0

30.0

211.0

1.0

199.0

1.0

197.0

2.0
$<.7$

$<.7$

17.85

$<.7$

27.69

$<.7$

381.37

$<.7$

208.27

$<.7$

380.61

$<.7$

23.78

$<.7$

21.77

$<.7$

22.6

4.2

39.6

.7

37.4

.7

39.0

.7
134.96

$<.71$

91.67

$<.71$

122.02

$<.71$

1596.2

$<.71$

961.5

$<.71$

158.08

$<.71$

98.69

$<.71$

93.02

$<.71$

98.0

2.0

163.0

1.0

161.0

1.0

162.0

1.0 
Table 6. (Continued)

\section{Description}

$2480 \mathrm{ppm}$, with defoamer Slurry, $\mathrm{T}=2475$ minutes

Filtrate, $\mathrm{T}=2475$ minutes

Slurry, $\mathrm{T}=2745$ minutes

Filtrate, $\mathrm{T}=2745$ minutes

Slurry, $T=2925$ minutes

Filtrate, $\mathrm{T}=2925$ minutes

$4960 \mathrm{ppm}$, with defoamer

Slurry, $\mathrm{T}=2970$ minutes

Filtrate, $\mathrm{T}=2970$ minutes

Slurry, $\mathrm{T}=3240$ minutes

Filtrate, $\mathrm{T}=3240$ minutes

Slurry, $\mathrm{T}=3420$ minutes

Filtrate, $\mathrm{T}=3420$ minutes
$\underline{\mathrm{Ca}(\mathrm{ppm})}$

$\underline{F e(p p m)}$

$\underline{\mathrm{Mn}(\mathrm{ppm})}$

$\underline{\text { Ti(ppm) }}$

56.0

20.0

54.0

17.0

55.0

20.0

84.0

18.0

89.0

18.0

87.0

23.0
381.0

4.0

392.0

4.0

390.0

4.0

690.0

5.0

708.0

10.0

700.0

6.0
74.7

.7

76.7

.7

78.1

.8

135.8

1.1

135.9

.7

137.5

.7
568.0

311.0

1.0

318.0

1.0

326.0

1.0

1.0

587.0

1.0

584.0

1.0

\section{Axial Velocity}

Figure 5 is a plot of filtrate flux versus axial velocity of all solutions tested except for Suspended Fines. The figure shows that flux increases slightly until reaching a maximum around $9 \mathrm{f} / \mathrm{s}$ then levels off. This is a typical behavior associated with the formation of a filter cake. Flux increases after a filter cake is formed until the cake is packed then the flux will decrease. Statistical analysis indicates the filtrate flux increases significantly with axial velocity therefore formation of a filter cake on the filter surface is occurring. 


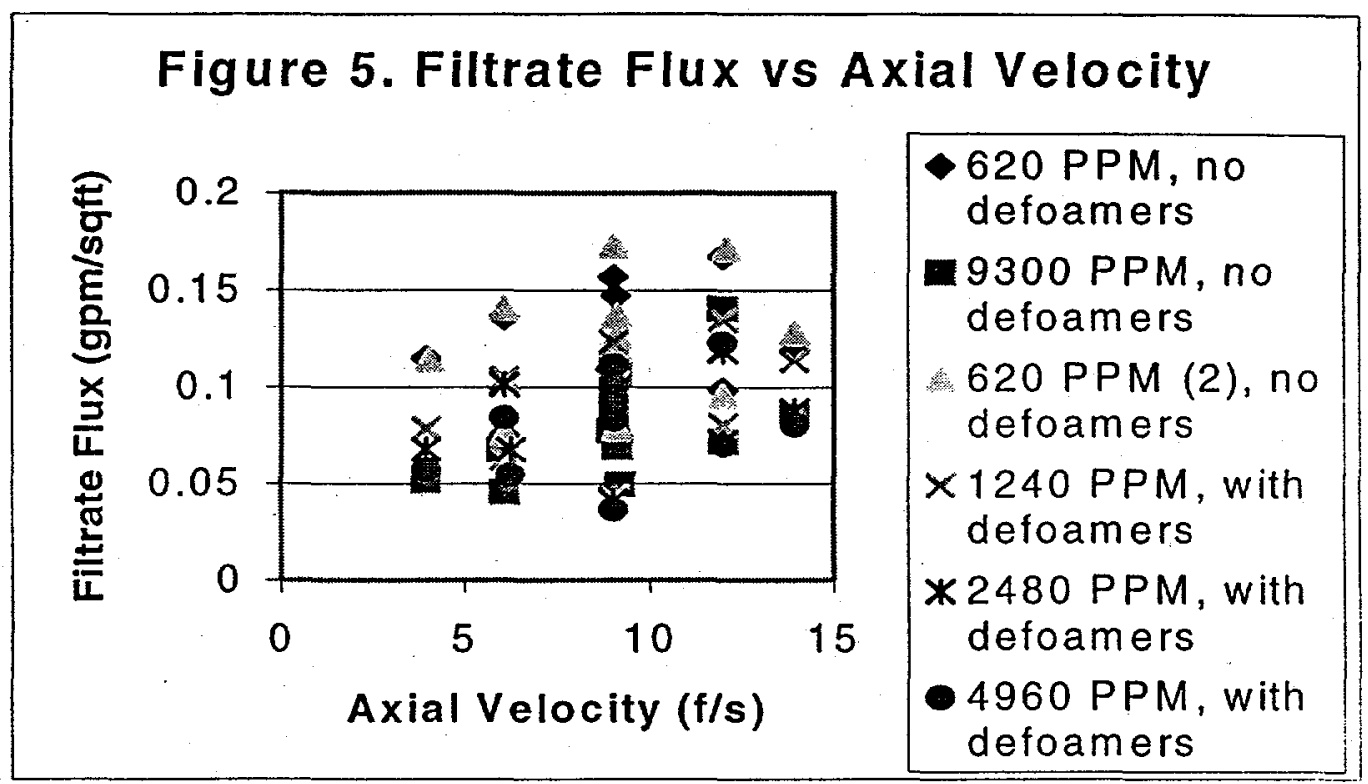

Plots and tables of data of individual tests are presented in the appendix for greater detail. The velocity was statistically significant with respect to flux for all filtration solutions tested which means that formation of a filter cake on the filter surface is causing an increase in filtrate flux response during filtration of these solutions.

\section{Transmembrane Pressure Drop}

A plot of the filtrate flux versus transmembrane pressure drop for all solutions tested except for Suspended Fines is given in Figure 6. Statistical analysis of the data indicates the filtrate flux increases with transmembrane pressure significantly. This means there is development of cake in the pores of the filter that causes an increase in filtrate flux response. Facility filtrate production rates can be improved by increasing the operating pressure over the range of the test conditions of 14 to $45 \mathrm{psi}$.

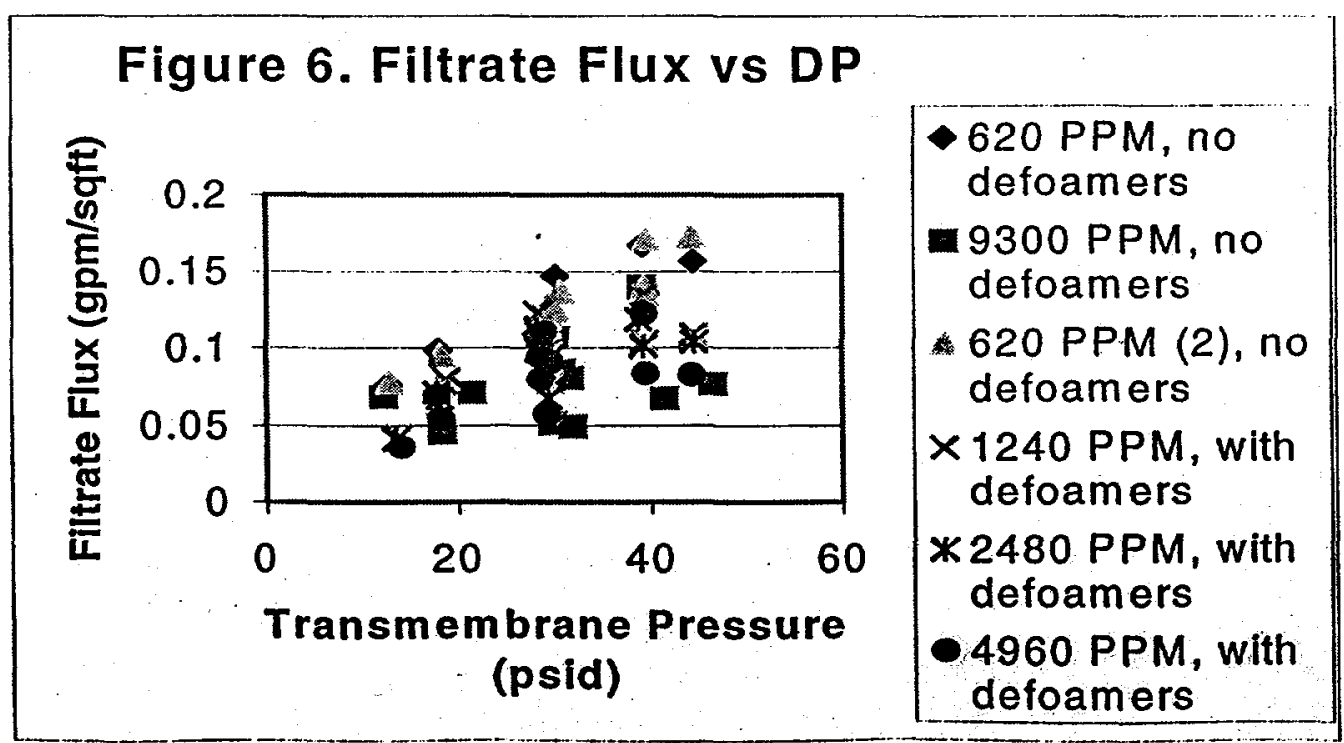


Plots and tables of individual filter tests are presented in the appendix for greater detail. The transmembrane pressure was statistically significant with respect to flux for all filtration solutions tested which means that formation of filter cake in the filter pores is causing a filtrate flux response during filtration of these solutions.

\section{Insoluble Solids}

As part of the experimental design, the importance of the presence of insoluble sludge and MST solids in the feed slurry was investigated. The influence of sludge and MST on filtrate flux can be observed in Figure 7. Analysis of the data indicates that the decrease in filtrate flux response is occurring with increasing sludge and MST concentration. The filtrate flux seems to level out after the $2480 \mathrm{ppm}$ concentration with no more decreases observed with increasing concentrations after this point.

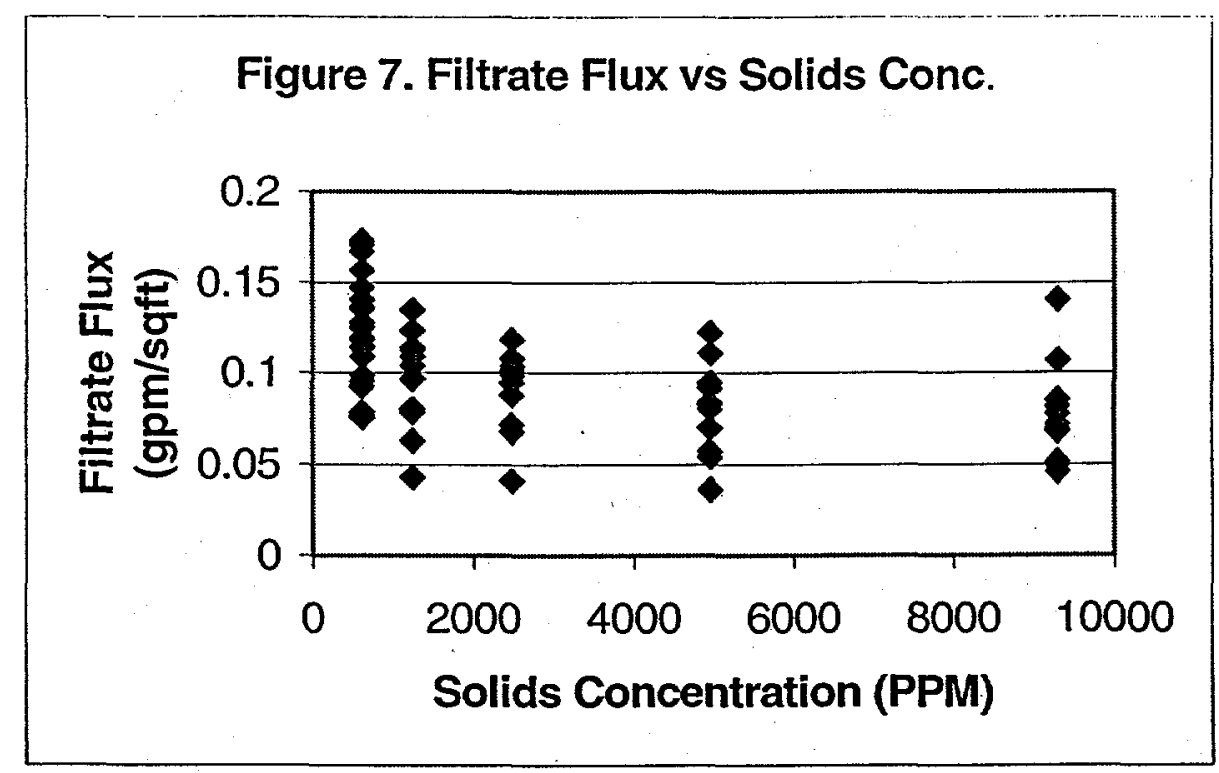

\section{Defoamers (Surfactants)}

Surfactant concentration effects on filtration flux are shown in Figure 8. Statistical analysis of the data indicates a filtrate flux decrease response with increased concentration of surfactants or defoamers. 


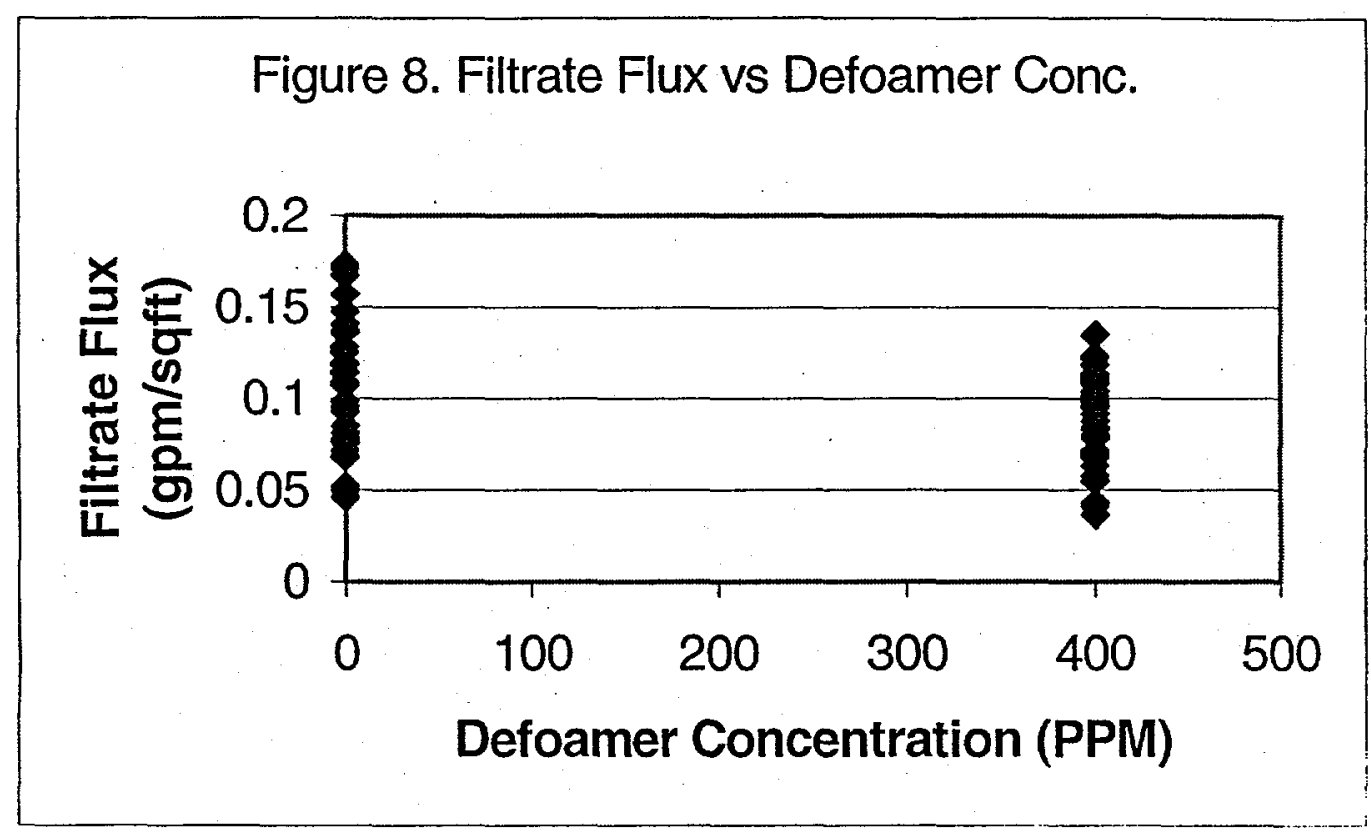

Filtrate Flux vs time

Linear regression of the filtration data for those solutions without defoamer predicts decrease in filter flux over time. This being statistically significant means there is a definite response when filtration time is increased. This response is not great in this case but there is a definite response of a small filtrate flux decrease.

Linear regression of the filtration data for those solutions with defoamer predicts decrease in filter flux over time. The data not being statistically significant means there is not a definite response ( $95 \%$ probability) when filtration time is increased. While the filtrate flux is seen to decrease slightly the decrease is not as great as the decrease with solutions with defoamers therefore it fails the $95 \%$ probability test.

\section{PREF Cleaning after Filter Studies}

The filter was cleaned first with 2 wt $\% \mathrm{NaOH}$ solution while backpulsing, followed by a deionized water rinse of the filter. A second cleaning solution of $2 \mathrm{wt} \%$ oxalic acid was then used while backpulsing. The filter was again rinsed with deionized water and an acceptable clean water flux was obtained.

\section{Conclusions}

Collection of a large body of experimental data on the filtration of sludge and MST in salt solution allowed development of an empirical model (Equation 2) to predict filtrate production over a variety of conditions. Filtrate flux is weakly dependent on the variables 
of insoluble solids concentration, defoamer concentration, transmembrane pressure, axial velocity, and filtration time.

Increasing transmembrane pressure and axial velocity slightly increases filtrate flux. When the transmembrane pressure is varied from $15-45$ psid the filtrate flux range was $0.04-0.17 \mathrm{gpm} / \mathrm{f}^{2}$ which included all ranges of solids and defoamer. Velocity being varied from 4 to $14 \mathrm{f} / \mathrm{s}$ for all ranges of solids and defoamer caused the flux to increase from .08 to $.1 \mathrm{gpm} / \mathrm{f}^{2}$.

Increasing solids concentration slightly decreases filtrate flux. When the concentration is increased from 620 to $9300 \mathrm{ppm}$ the filtrate flux decreases from a range of $.08-.17$ to .05 to $.14 \mathrm{gpm} / \mathrm{f}^{2}$. Filtration time decreases filtrate flux slightly when no defoamers are present. This occurs to a marginally lesser extent with solutions that have defoamers. When the concentration of defoamers is increased from 0 to $400 \mathrm{ppm}$ the filtrate flux decreases from the .05 to .17 range to .04 to $.13 \mathrm{gpm} / \mathrm{f}^{2}$.

The highest filtrate fluxes in the range of .46 to $1.02 \mathrm{gpm} / \mathrm{f}^{2}$ were obtained when salt solution decanted form settled solid (Suspended Fines Solution) was filtered. This could be used as a possible run scenario for the plant. It the waste tank agitator is turned off and the solution allowed to settle for several days the resulting Suspended Fines Solution can be filtered leaving the solids in the bottom of the tank.

Filtrate flux rates between .04 to $.17 \mathrm{gpm} / \mathrm{f}^{2}$ which were obtained with the PREF would predict ITP filtrate production of 9.2 to $31.4 \mathrm{gpm}$ to be obtained for solids concentrations between 620 and $9300 \mathrm{ppm}$ insoluble solids concentrations.

Additions of defoamers decreased the filtrate flux to a range of .04 to $.13 \mathrm{gpm} / \mathrm{f}^{2}$. This is close to the ITP flux of $.25 \mathrm{gpm} / \mathrm{f}^{2}$ for $0-4 \mathrm{wt} \%$ solids loading at a transmembrane pressure of 6 psid predicted by their design basis.

Using the model in this report, it will be possible to predict the performance of the facility using sludge and MST in salt solution slurries. Additional filter tests involving a larger scale system are being performed at the University of South Carolina to ensure the scalability of these results. A statistical analysis of these results will be performed with the intent of improving the certainty of the predictions of filter performance. 
WSRC-TR-98-00364 RoO

Page 18 of 30

Bibliography

'C. A. Nash, "Test Outline for the Filter Research Unit Salt Disposition Alternatives Support", WSRC-RP-98-00691, July 20, 1998.

${ }^{2}$ M. F. Morrissey, "Investigating Salt Solution", WSRC-RP-93-1168, September 25. 1993.

${ }^{3}$ L. F. Landon, "Technical Bases - DWPF Late Washing Facility", WSRC-RP-92-793, February 7, 1994.

Authors

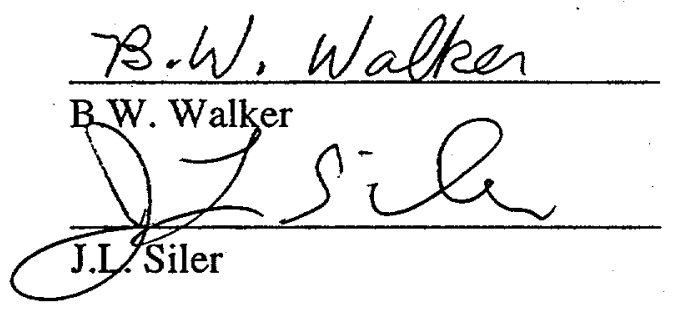

Design Check

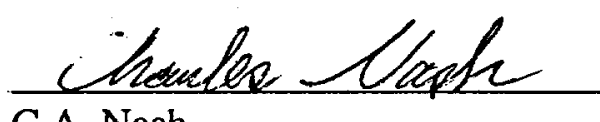

C.A. Nash

Level 4 Manager

W.b. Van Ret

W.B. Van Pelt

Level 3 Manager

latium

W.E. Stevens
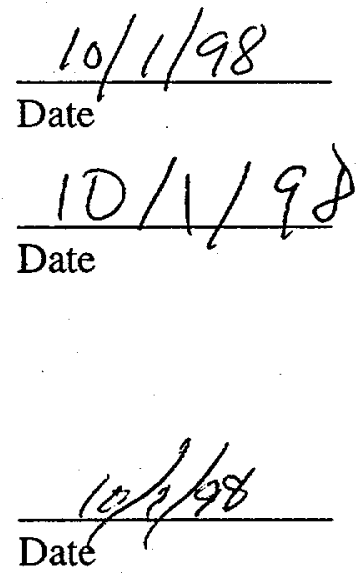

$\frac{10-1-98}{\text { Date }}$

$\frac{10 / 1 / 98}{\text { Date }}$ 


\section{Appendix}

\begin{tabular}{|c|c|c|c|c|c|}
\hline $\begin{array}{l}\text { Defoamer } \\
\text { Conc } \\
\text { (ppm) }\end{array}$ & $\begin{array}{l}\text { Trans. } \\
\text { Press } \\
\text { (psid) }\end{array}$ & $\begin{array}{l}\text { Total } \\
\text { solids } \\
\text { (ppm) }\end{array}$ & $\begin{array}{l}\text { Axial } \\
\text { Velocity } \\
\text { (f/s) }\end{array}$ & Time(min) & $\begin{array}{l}\text { Filtrate } \\
\text { Flux } \\
\text { (gpm/sqft) }\end{array}$ \\
\hline & $0 \quad 30.08$ & 620 & 9.09 & 540 & 0.15 \\
\hline & 39.15 & 620 & 11.97 & 585 & 0.17 \\
\hline & 29.16 & 620 & 3.94 & 630 & 0.11 \\
\hline & 12.68 & 620 & 9.02 & 675 & 0.08 \\
\hline & 17.89 & 620 & 11.97 & 720 & 0.1 \\
\hline & 28.09 & 620 & 8.94 & 765 & 0.11 \\
\hline & 39.43 & 620 & 6.07 & 810 & 0.14 \\
\hline & 44.39 & 620 & 9.02 & 855 & 0.16 \\
\hline & 28.9 & 620 & 13.94 & 900 & 0.12 \\
\hline & 19.13 & 620 & 6.07 & 945 & 0.08 \\
\hline & 29.28 & 620 & 9.02 & 990 & 0.09 \\
\hline
\end{tabular}



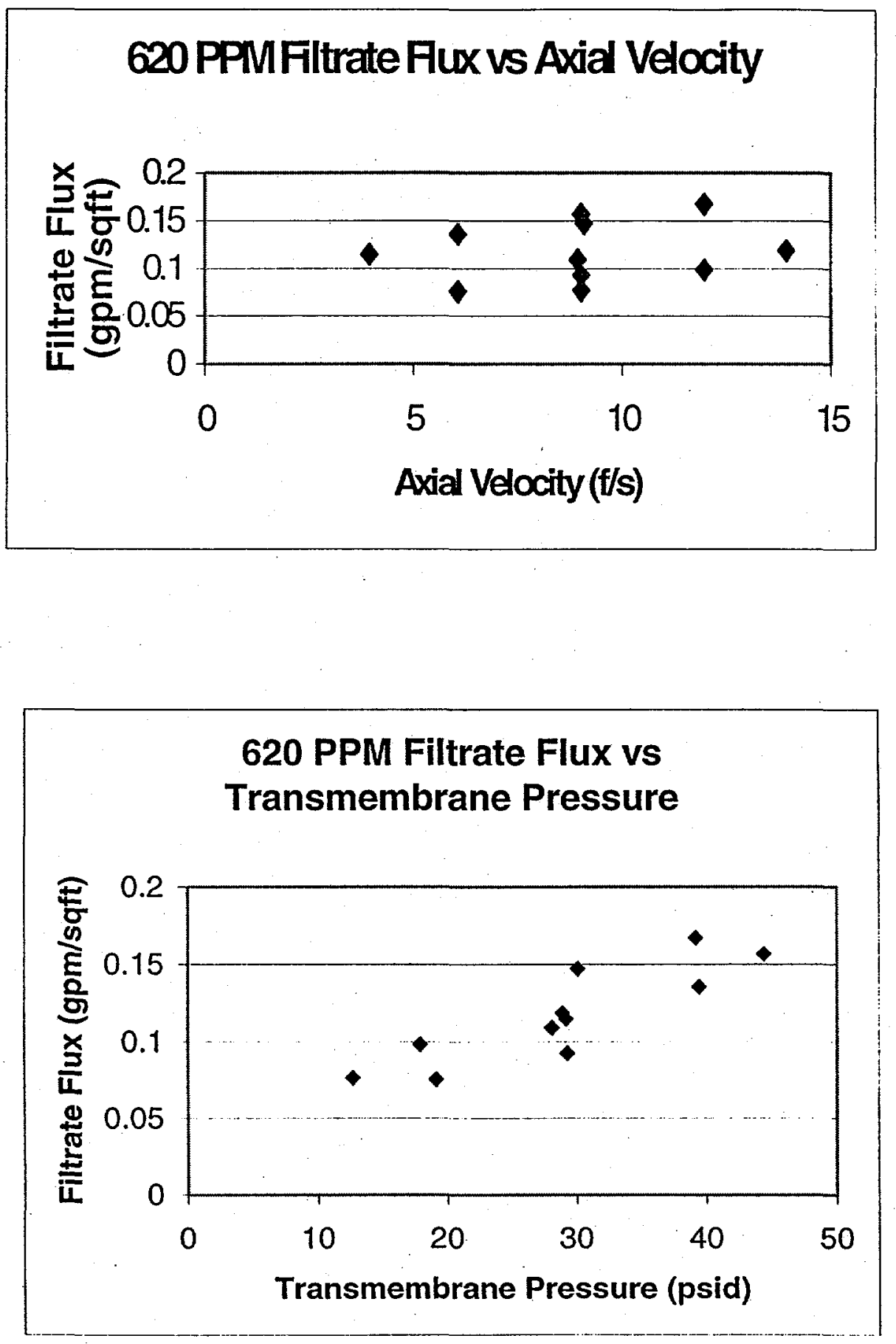


\begin{tabular}{|c|c|c|c|c|c|}
\hline $\begin{array}{l}\text { Defoamer } \\
\text { Conc } \\
\text { (ppm) }\end{array}$ & $\begin{array}{l}\text { Trans. } \\
\text { Press } \\
\text { (psid) }\end{array}$ & $\begin{array}{l}\text { Total } \\
\text { solids } \\
\text { (ppm) }\end{array}$ & $\begin{array}{l}\text { Axial } \\
\text { Velocity } \\
(f / s)\end{array}$ & Time(min) & $\begin{array}{l}\text { Filtrate } \\
\text { Flux } \\
\text { (gpm/sqft) }\end{array}$ \\
\hline & 30.02 & 9300 & 9.1 & 1035 & 0.11 \\
\hline & 39.01 & 9300 & 11.97 & 1080 & 0.14 \\
\hline & 29.76 & 9300 & 3.94 & 1125 & 0.05 \\
\hline & 12.24 & 9300 & 9.1 & 1170 & 0.07 \\
\hline & 21.41 & 9300 & 11.97 & 1215 & 0.07 \\
\hline & 31.61 & 9300 & 9.02 & 1260 & 0.08 \\
\hline & 41.41 & 9300 & 5.98 & 1305 & 0.07 \\
\hline & 46.45 & 9300 & 8.94 & 1350 & 0.08 \\
\hline & 30.74 & 9300 & 13.94 & 1395 & 0.09 \\
\hline & 18.35 & 9300 & 6.07 & 1440 & 0.05 \\
\hline & 31.83 & 9300 & 9.18 & 1485 & 0.05 \\
\hline
\end{tabular}



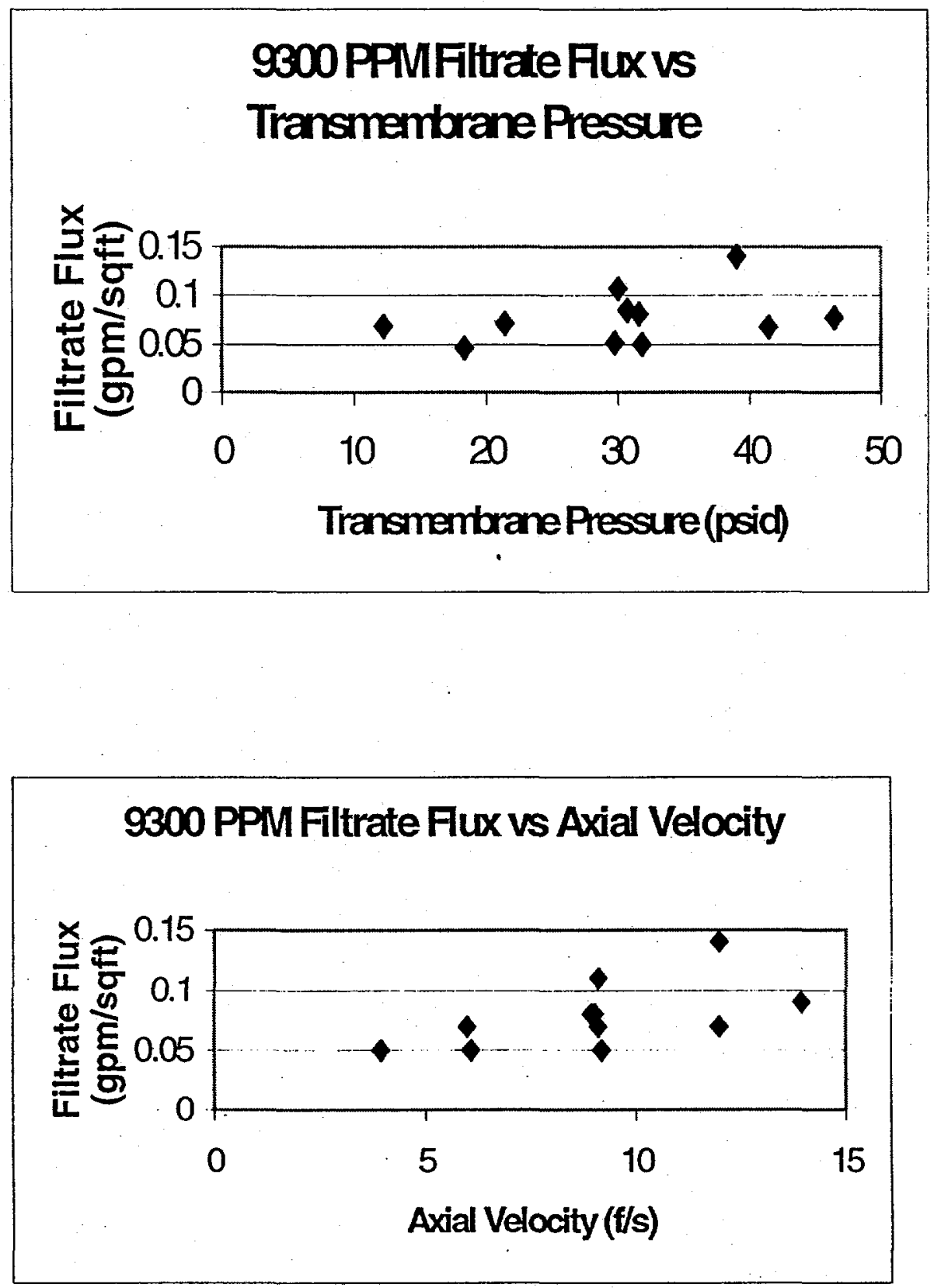


\begin{tabular}{|c|c|c|c|c|c|c|}
\hline $\begin{array}{l}\text { Defoame } \\
\text { Conc } \\
\text { (ppm) }\end{array}$ & & & $\begin{array}{l}\text { Total } \\
\text { solids } \\
\text { (ppm) }\end{array}$ & $\begin{array}{l}\text { Axial } \\
\text { Velocity } \\
(f / s)\end{array}$ & Time(min) & $\begin{array}{l}\text { Filtrate } \\
\text { Flux } \\
\text { (gpm/sqft) }\end{array}$ \\
\hline & 0 & 30.52 & 620 & 9.1 & 1530 & 0.14 \\
\hline & 0 & 39.41 & 620 & 12.05 & 1575 & 0.17 \\
\hline & 0 & 29.28 & 620 & 4.02 & 1620 & 0.11 \\
\hline & 0 & 12.81 & 620 & 9.1 & 1665 & 0.08 \\
\hline & 0 & 18.13 & 620 & 11.97 & 1710 & 0.1 \\
\hline & 0 & 29.32 & 620 & 9.1 & 1755 & 0.12 \\
\hline & 0 & 39.24 & 620 & 6.07 & 1800 & 0.14 \\
\hline & 0 & 44.25 & 620 & 9.02 & 1845 & 0.17 \\
\hline & 0 & 29.37 & 620 & 13.94 & 1890 & 0.13 \\
\hline & 0 & 17.95 & 620 & 6.07 & 1935 & 0.08 \\
\hline & 0 & 29.91 & 620 & 9.1 & 1980 & 0.13 \\
\hline
\end{tabular}



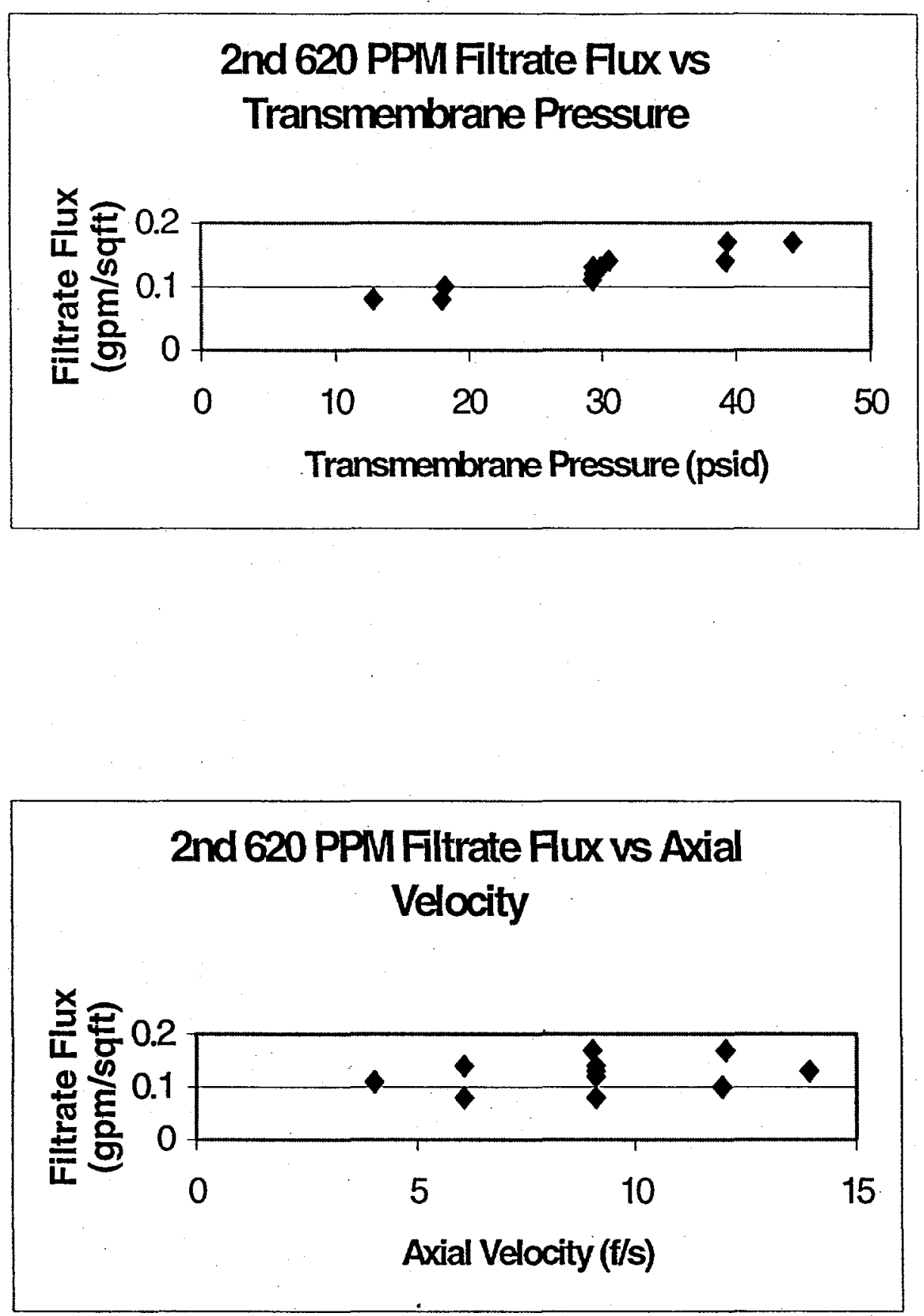
WSRC-TR-98-00364 R0

Page 25 of $30^{\circ}$

\begin{tabular}{lrlrlr}
$\begin{array}{l}\text { Defoamer } \\
\text { Conc } \\
\text { (ppm) }\end{array}$ & $\begin{array}{l}\text { Trans. } \\
\text { Press } \\
\text { (psid) }\end{array}$ & \multicolumn{1}{l}{$\begin{array}{l}\text { Total } \\
\text { solids } \\
\text { (ppm) }\end{array}$} & \multicolumn{2}{l}{$\begin{array}{l}\text { Axial } \\
\text { Velocity } \\
\text { (f/s) }\end{array}$} & \multicolumn{2}{l}{ Time(min) $\begin{array}{l}\text { Filtrate } \\
\text { Flux } \\
\text { (gpm/sqft) }\end{array}$} \\
400 & 28.21 & 1240 & 9.02 & 2025 & 0.12 \\
400 & 39.22 & 1240 & 11.97 & 2070 & 0.13 \\
400 & 29.55 & 1240 & 3.94 & 2115 & 0.08 \\
400 & 13.77 & 1240 & 9.02 & 2160 & 0.04 \\
400 & 18.74 & 1240 & 11.97 & 2205 & 0.08 \\
400 & 28.54 & 1240 & 9.02 & 2250 & 0.11 \\
400 & 39.3 & 1240 & 6.07 & 2295 & 0.1 \\
400 & 44.41 & 1240 & 9.02 & 2340 & 0.11 \\
400 & 28.2 & 1240 & 13.94 & 2385 & 0.11 \\
400 & 18.03 & 1240 & 6.07 & 2430 & 0.06 \\
400 & 29.45 & 1240 & 9.02 & 2475 & 0.1
\end{tabular}



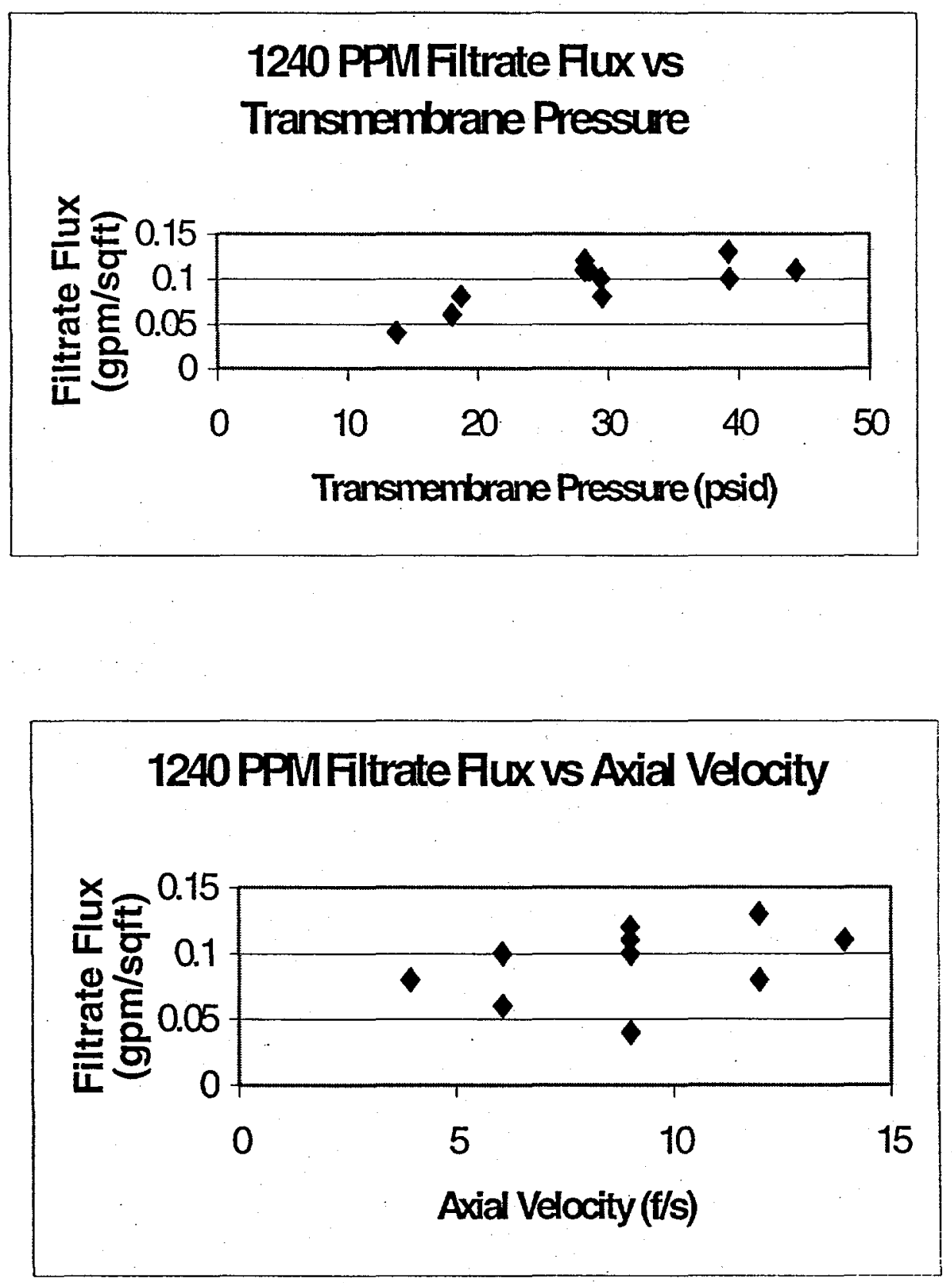


\begin{tabular}{lllrlr}
$\begin{array}{l}\text { Defoamer } \\
\text { Conc } \\
\text { (ppm) }\end{array}$ & $\begin{array}{l}\text { Trans. } \\
\text { Press } \\
\text { (psid) }\end{array}$ & \multicolumn{1}{c}{$\begin{array}{l}\text { Total } \\
\text { solids } \\
\text { (ppm) }\end{array}$} & $\begin{array}{l}\text { Axial } \\
\text { Velocity } \\
\text { (f/s) }\end{array}$ & \multicolumn{2}{l}{ Time(min) $\begin{array}{l}\text { Filtrate } \\
\text { Flux } \\
\text { (gpm/sqft) }\end{array}$} \\
400 & 28.56 & 2480 & 9.02 & 2520 & 0.11 \\
400 & 38.65 & 2480 & 11.97 & 2565 & 0.12 \\
400 & 29.34 & 2480 & 3.94 & 2610 & 0.07 \\
400 & 13.52 & 2480 & 9.02 & 2655 & 0.04 \\
400 & 17.73 & 2480 & 11.97 & 2700 & 0.07 \\
400 & 28.38 & 2480 & 9.02 & 2745 & 0.1 \\
400 & 39.19 & 2480 & 6.07 & 2790 & 0.1 \\
400 & 44.56 & 2480 & 9.02 & 2835 & 0.1 \\
400 & 28.69 & 2480 & 13.94 & 2880 & 0.09 \\
400 & 18.08 & 2480 & 6.23 & 2925 & 0.07 \\
400 & 29.65 & 2480 & 9.02 & 2970 & 0.09
\end{tabular}



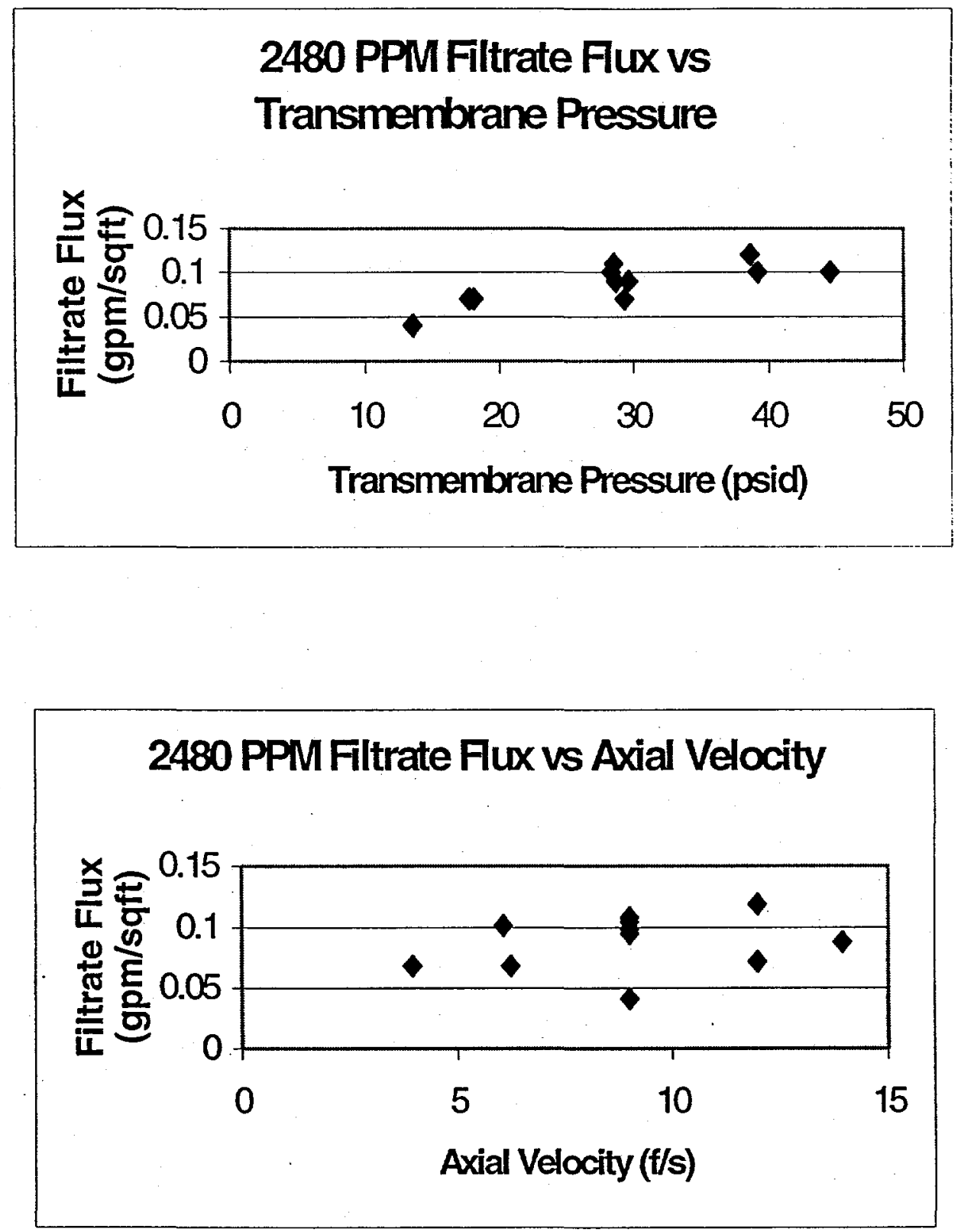
WSRC-TR-98-00364 R0

Page 29 of 30

\begin{tabular}{|c|c|c|c|c|c|}
\hline $\begin{array}{l}\text { Defoamer } \\
\text { Conc } \\
\text { (ppm) }\end{array}$ & $\begin{array}{l}\text { Trans. } \\
\text { Press } \\
\text { (psid) }\end{array}$ & $\begin{array}{l}\text { Total } \\
\text { solids } \\
\text { (ppm) }\end{array}$ & $\begin{array}{l}\text { Axial } \\
\text { Velocity } \\
\text { (t/s) }\end{array}$ & Time(min) & $\begin{array}{l}\text { Filtrate } \\
\text { Flux } \\
\text { (gpm/sqft) }\end{array}$ \\
\hline 400 & 28.85 & 4960 & 9.02 & 3015 & 0.11 \\
\hline 400 & 39.25 & 4960 & 11.97 & 3060 & 0.12 \\
\hline 400 & 29.17 & 4960 & 3.94 & 3105 & 0.06 \\
\hline 400 & 14.07 & 4960 & 9.02 & 3150 & 0.04 \\
\hline 400 & 17.79 & 4960 & 11.97 & 3195 & 0.07 \\
\hline 400 & 28.55 & 4960 & 9.02 & 3240 & 0.09 \\
\hline 400 & 39.49 & 4960 & 6.07 & 3285 & 0.08 \\
\hline 400 & 44.31 & 4960 & 9.02 & 3330 & 0.08 \\
\hline 400 & 28.56 & 4960 & 13.94 & 3375 & 0.08 \\
\hline 400 & 18.2 & 4960 & 6.23 & 3420 & 0.05 \\
\hline 400 & 29.61 & 4960 & 9.02 & 3465 & 0.09 \\
\hline
\end{tabular}



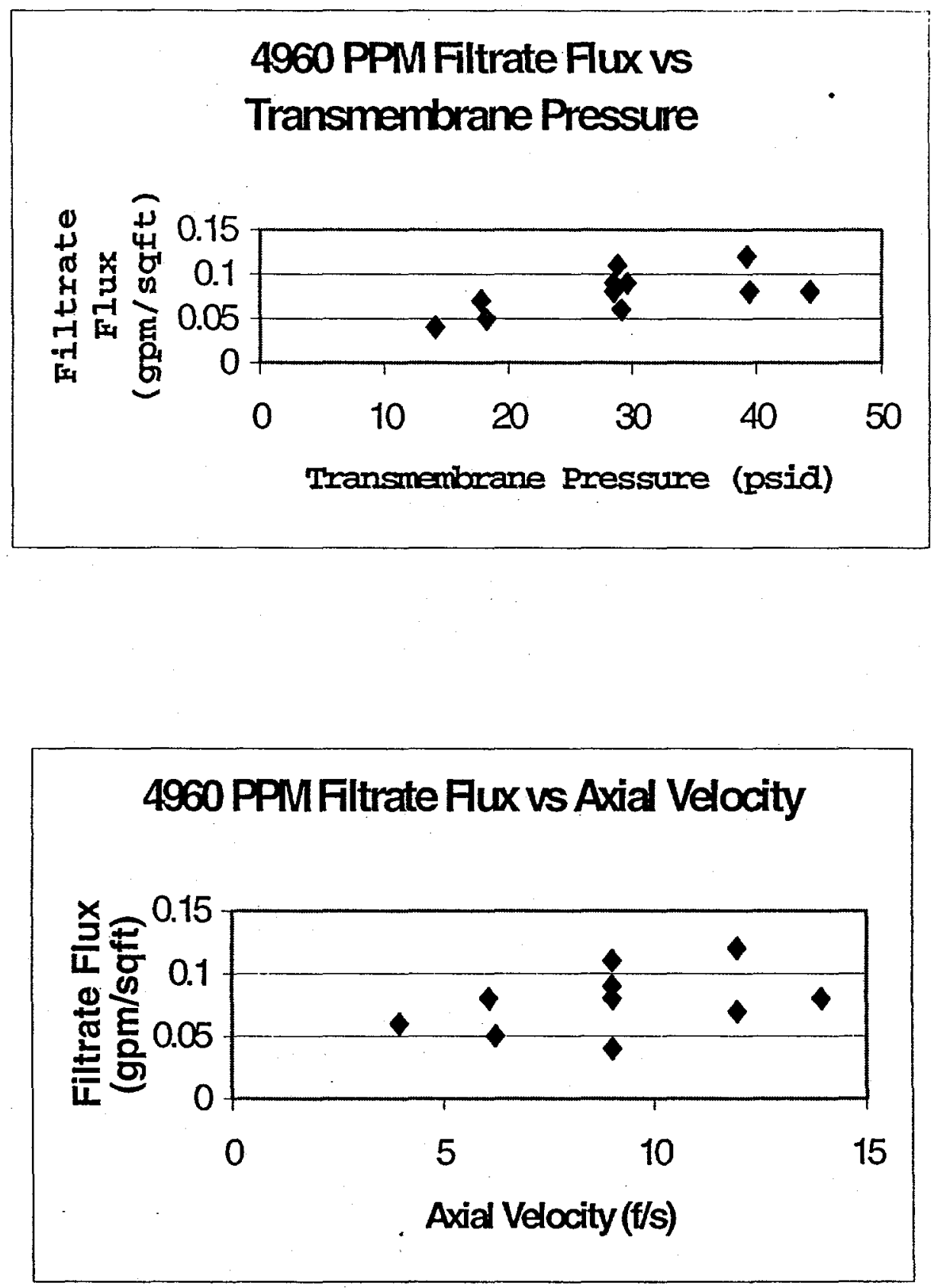